Vol. 2. No. 1 Januari 2013

\title{
ANALISIS KINERJA PERFORMANCE UJIAN NASIONAL TAHUN 2013
}

\author{
Oleh : Rani Susanti
}

\begin{abstract}
Abstrak. Penelitian ini bertujuan untuk menguji salah satu kebijakan publik dalam bidang pendidikan serta upaya kritisasi terhadap pemerintah atas dasar kinerja performance ujian naional 2013 yang tidak hanya melibatkan pemerintah dan masyarakat tetapi juga lembaga legislatif, badan eksekutif dan juga lembaga yudisial. Penelitian ini berfokus kepada penetapan kebijakan ujian nasional yang mencakup proses inisiasi, formulasi, legislasi, dan otoritas kebijakan ujian nasional. Implementasi lokal kebijakan ujian nasional yang mencakup tahap persiapan, tahap pelaksanaan, tahap pelaporan ujian nasional didaerah. Penelitian ini penting tidak hanya bagi kepala sekolah dan guru, pengawas sekolah dan dinas pendidikan, tetapi juga bagi Badan Standar Nasional Pendidikan, Direktur Jendral Pendidikan Dasar dan Menengah, panitia Kinerja Ujian Nasional DPR RI, lembaga advokasi pendidikan, serta peneliti, baik kebijakan pendidikan secara umum, maupun secara khusus kebijakan ujian nasional. Sasaran diajukan kepada : Dosen mata kuliah Teknologi Kinerja di Universitas Ibnu Khaldun - Bogor yakni Dr. Zainal Abidin Arief, M. Sc.
\end{abstract}

Kata Kunci : Kebijakan Publik, Analisis Ujian Nasional, Evaluasi Ujian Nasional.

This study aims to test one of public policy in the field of education as well as the efforts of criticism against the government on the basis of performance test performance Naional 2013 that not only involves the government and society, but also the legislature, the executive and judicial institutions. This research focuses on policy-setting national exam that covers the process of initiation, formulation, legislation, and policy authorities of national exams. Local implementation of national policy that includes exam preparation phase, implementation phase, test phase of the national reporting area. Penelittian is important not only for principals and teachers, and the school superintendent of education, but also for National Education Standards Agency, Director General of Primary and Secondary Education, the National Examination Performance committee of Parliament, the institution of education, advocacy and research, both in education policy general, and in particular the policy of national exams. Target submitted to: Lecturer Performance Technology course at the University of Ibn Khaldun - Bogor namely Dr. Abidin Zainal Arief, M. Sc.

Keywords: Public Policy, National Exam Analysis, Evaluation of the National Exam.

\section{PENDAHULUAN}

\section{LATAR BELAKANG}

Analisis adalah suatu kegiatan yang terencana untuk mengetahui keadaan suatu objek dengan menggunakan instrumen dan hasilnya dibandingkan dengan suatu tolak ukur untuk memperoleh suatu kesimpulan. Fungsi utama Analisis adalah menelaah suatu objek atau keadaan untuk mendapatkan informasi yang tepat sebagai dasar untuk pengambilan keputusan. 
Sesuai pendapat Grondlund dan Linn (1990) mengatakan bahwa evaluasi pembelajaran adalah suatu proses mengumpulkan, menganalisis dan menginterprestasi informasi secara sistematik untuk menetapkan sejauh mana ketercapaian tujuan pembelajaran.

Berdasar pada pengertian di atas, jurnal ini akan membahas beberapa analisis yang akan menghasilkan evaluasi dari kegiatan Ujian Nasional atau UN / UNAS yang baru saja dilaksanakan.

Tak lupa saya mengucapkan terima kasih kepada Bapak Dr. Zainal yang telah memberikan tugas analisis performance ujian nasinal. Semoga Allah swt berkenan membalasnya dengan pahala yang pantas di sisi-Nya. Amiiin.

Rumusan masalah dalam jurnal ini adalah sebagai berikut:

1. Apa pengertian pendidikan ?

2. Apa pengertian ujian nasional ?

3. Apa itu Barcode ?

4. Bagaimana upaya Kritis dan evaluasi atas Ujian nasional 2013 ?

\section{KAJIAN TOERI PENDIDIKAN DAN UJIAN NASIONAL}

\section{PENGERTIAN PENDIDIKAN}

Kata pendidikan menurut Sholeh Abdul Aziz dan Abdul Aziz Abdul Majid, pendidikan adalah:

$$
\text { لتَّر بيّة هي المؤثرات المختلفات التّى توجّه }
$$
وتسطر على حياة الفرد

Artinya : "Pendidikan adalah berbagai macam aktivitas yang mengarah kepada pembentukan kepribadian individu".

Menurut Frederick J. Mc. Donald, "Education is a process or an activity wich is directed at producing desirable changes in the behavior of human beings". Artinya: pendidikan adalah sebuah proses atau sebuah aktivitas yang bertujuan untuk menghasilkan perubahan yang diinginkan pada tingkah laku manusia.

Dengan demikian, sekolah merupakan lembaga formal yang melaksanakan pendidikan yang didalamnya mencakup kurikulum.

\section{DEFINISI PENDIDIKAN MENURUT ISLAM}

Pendidikan Islam itu sendiri adalah pendidikan yang berdasarkan Islam. Isi ilmu adalah teori. Isi ilmu bumi adalah teori tentang bumi. Maka isi Ilmu pendidikan adalah teori-teori tentang pendidikan, IImu pendidikan Islam secara lengkap isi suatu ilmu bukanlah hanya teori. (Nur Uhbiyati, 1998).

Pengertian pendidikan bahkan lebih diperluas cakupannya sebagai aktivitas dan fenomena. Pendidikan sebagai aktivitas berarti upaya yang secara sadar dirancang untuk membantu seseorang atau sekelompok orang dalam mengembangkan pandangan hidup, sikap hidup, dan keterampilan hidup, baik yang bersifat manual (petunjuk praktis) maupun mental, dan sosial sedangkan pendidikan sebagai fenomena adalah peristiwa perjumpaan antara dua orang atau lebih yang dampaknya ialah berkembangnya suatu pandangan hidup, sikap hidup, atau keterampilan hidup pada salah satu atau beberapa pihak, yang kedua pengertian ini harus bernafaskan atau dijiwai oleh ajaran dan nilai-nilai Islam yang bersumber dari al Qur'an dan Sunnah (Hadist).

\section{Ruang Lingkup Pendidikan Islam}

\section{a. Pendidikan Keimanan}


"Dan ingatlah ketika Luqman berkata kepada anaknya diwaktu ia memberikan pelajaran kepadanya: "hai anakku, janganlah kamu mempersekutukan Allah, sesengguhnya mempersekutukan Allah adalah benar-benar kedzaliman yang nyata." (Q.S 31:13)

Bagaimana cara mengenalkan Allah SWT dalam kehidupan anak?

1) Menciptakan hubungan yang hangat dan harmonis (bukan memanjakan) Jalin hubungan komunikasi yang baik dengan anak, bertutur kata lembut, bertingkah laku positif.

Hadits Rasulullah : "cintailah anakanak kecil dan sayangilah mereka...:" (H.R Bukhari)

"Barang siapa mempunyai anak kecil, hendaklah ia turut berlaku kekanakkanakkan kepadanya." (H.R Ibnu Babawaih dan Ibnu Asakir)

2) Menghadirkan sosok Allah melalui aktivitas rutin

Seperti ketika kita bersin katakan alhamdulillah. Ketika kita memberikan uang jajan katakan bahwa uang itu titipan Allah jadi harus dibelanjakan dengan baik seperti beli roti.

3) Memanfaatkan momen religious

Seperti Sholat bersama, tarawih bersama di bulan ramadhan, tadarus, buka shaum bareng.

4) Memberi kesan positif tentang Allah dan kenalkan sifat-sifat baik Allah

Jangan mengatakan " nanti Allah marah kalau kamu berbohong" tapi katakanlah " anak yang jujur disayang Allah".
5) Beri teladan

Anak akan bersikap baik jika orang tuanya bersikap baik karena anak menjadikan orang tua model atau contoh bagi kehidupannya.

"hai orang-orang yang beriman mengapa kamu mengatakan apa yang tidak kamu perbuat? Amat besar di sisi Allah bahwa kamu mengatakan apaapa yang tiada kamu kerjakan".(Q.S 61:2-3)

6) Kreatif dan terus belajar

Sejalan dengan perkembangan anak. Anak akan terus banyak memberikan pertanyaan. Sebagai orang tua tidak boleh merasa bosan dengan pertanyaan anak malah kita harus dengan bijaksana menjawab segala pertanyaannya dengan mengikuti perkembangan anak.

\section{b. Pendidikan Akhlak} bersabda:

Hadits dari Ibnu Abas Rasulullah

"... Akrabilah anak-anakmu dan didiklah akhlak mereka."

Rasulullah saw bersabda:

"Suruhlah anak-anak kamu melakukan shalat ketika mereka telah berumur tujuh tahun dan pukullah mereka kalau meninggalkan ketika mereka berumur sepuluh tahun, dan pisahkan tempat tidur mereka." (HR. Abu Daud).

Bagaimana cara megenalkan akhlak kepada anak :

1) Penuhilah kebutuhan emosinya

Dengan mengungkapkan emosi lewat cara yang baik. 
Hindari mengekspresikan emosi dengan cara kasar, tidak santun dan tidak bijak. Berikan kasih sayang sepenuhnya, agar anak merasakan bahwa ia mendapatkan dukungan.

Hadits Rasulullah : " Cintailah anakanak kecil dan sayangilah mereka ...:" (H.R Bukhari)

2) Memberikan pendidikan mengenai yang haq dan bathil

"Dan janganlah kamu campur adukan yang haq dengan yang bathil dan janganlah kamu sembunyikan yang haq itu, sedang kamu mengetahui ."(Q.S 2:42)

Seperti bahwa berbohong itu tidak baik, memberikan sedekah kepada fakir miskin itu baik.

3) Memenuhi janji

Hadits Rasulullah :"... Jika engkau menjanjikan sesuatu kepada mereka, penuhilah janji itu. Karena mereka itu hanya dapat melihat, bahwa dirimulah yang memberi rizki kepada mereka." (H.R Bukhari)

4) Meminta maaf jika melakukan kesalahan

5) Meminta tolong/mengatakan tolong jika kita memerlukan bantuan.

6) Mengajak anak mengunjungi kerabat

\section{c. Pendidikan intelektual}

Menurut kamus Psikologi istilah intelektual berasal dari kata intelek yaitu proses kognitif/berpikir, atau kemampuan menilai dan mempertimbangkan.

Pendidikan intelektual ini disesuaikan dengan kemampuan berpikir anak. Menurut Piaget seorang Psikolog yang membahas tentang teori perkembangan yang terkenal juga dengan Teori Perkembangan Kognitif mengatakan ada 4 periode dalam perkembangan kognitif manusia, yaitu:

1) Periode 1, 0 tahun - 2 tahun (sensori motorik)

Mengorganisasikan tingkah laku fisik seperti menghisap, menggenggam dan memukul pada usia ini cukup dicontohkan melalui seringnya dibacakan ayat-ayat suci al-Quran atau ketika kita beraktivitas membaca bismillah.

2) Periode 2, 2 tahun - 7 tahun (berpikir Pra Operasional)

Anak mulai belajar untuk berpikir dengan menggunakan symbol dan khayalan mereka tapi cara berpikirnya tidak logis dan sistematis.

Seperti contoh nabi Ibrahim mencari Robbnya.

3) Periode 3, 7 tahun- 11 tahun (Berpikir Kongkrit Operasional)

Anak mengembangkan kapasitas untuk berpikir sistematik

Contoh : Angin tidak terlihat tetapi dapat dirasakan begitu juga dengan Allah SWT tidak dapat dilihat tetapi ada ciptaannya.

4) Periode 4, 11 tahun- Dewasa (Formal Operasional)

Kapasitas berpikirnya sudah sistematis dalam bentuk abstrak dan konsep

\section{d. Pendidikan fisik}

Dengan memenuhi kebutuhan makanan yang seimbang, memberi waktu tidur dan aktivitas yang cukup agar pertumbuhan fisiknya baik dan mampu 
melakukan aktivitas seperti yang disunahkan Rasulullah

"Ajarilah anak-anakmu memanah, berenang dan menunggang kuda." (HR. Thabrani)

\section{e. Pendidikan Psikis}

"Dan janganlah kamu bersifat lemah dan jangan pula berduka cita, padahal kamulah orang-orang yang paling tinggi derajatnya, jika kamu benar-benar orang yang beriman." (QS. 3:139)

1) Memberikan kebutuhan emosi, dengan cara memberikan kasih saying, pengertian, berperilaku santun dan bijak.

2) Menumbuhkan rasa percaya diri

3) Memberikan semangat tidak melemahkan

\section{DEFINISI PENDIDIKAN MENURUT PERSPEKTIF NASIONAL}

Pendidikan pada dasarnya merupakan suatu upaya pedagogis untuk mentransfer sejumlah nilai yang dianut oleh masyarakat suatu bangsa kepada sejumlah subjek didik melalui proses pembelajaran. Sistem nilai tersebut tertuang dalam sistem pendidikan yang dirumuskan dalam dasar-dasar pandangan hidup bangsa itu. Rumusan pandangan hidup tersebut kemudian dituangkan dalam Undang-Undang Dasar dan perundang-undangan. Dalam UndangUndang Dasar dan perundang-undangan itu pandangan filosofis suatu bangsa di antaranya tercermin dalam sistem pendidikan yang dijalankan.

Bagi bangsa Indonesia, pandangan filosofis mengenai pendidikan dapat dilihat pada tujuan nasional sebagaimana termaktub dalam Pembukaan UndangUndang Dasar 1945 paragraf keempat. Secara umum tujuan pendidikan nasional adalah untuk mencerdaskan kehidupan bangsa. Kemudian secara terperinci dipertegas lagi dalam Undang-undang Nomor 20 Tahun 2003 tentang Sistem Pendidikan Nasional.

\section{PENGERTIAN TES DAN EVALUASI}

Instrumen atau alat yang digunakan untuk memperoleh informasi tentang individu atau objek. Sebagai alat pengumpul informasi atau data, tes harus dirancang secara khusus. Kekhususan tes terlihat dari bentuk soal tes yang digunakan, jenis pertanyaan, rumusan pertanyaan yang diberikan, dan pola jawabannya harus dirancang menurut kriteria yang telah ditetapkan. Demikian juga waktu yang disediakan untuk menjawab pertanyaan serta pengadministrasian tes juga dirancang secara khusus. Selain itu aspek yang diteskanpun terbatas. Biasanya meliputi ranah kognitif, afektif, dan psikomotor. Kekhususan-kekhususan tersebut berbeda antara satu tes dengan tes yang lain.

Tes ini dapat berupa pertanyaan tertulis, wawancara, pengamatan tentang unjuk kerja fisik, checklist, dan lain-lain. Pengukuran adalah proses pengumpulan data atau informasi yang dilakukan secara objektif. Melalui kegiatan pengukuran segala program yang menyangkut perkembangan dalam bidang apa saja dapat dikontrol dan dievaluasi. Hasil pengukuran berupa kuantifikasi dari jarak, waktu, jumlah, dan ukuran dsb.

Hasil dari pengukuran dinyatakan dalam bentuk angka yang dapat diolah secara statistik. Evaluasi selalu dilaksanakan 
dengan merujuk kepada tujuan yang ingin dicapai dalam suatu kegiatan.

Evaluasi merupakan proses pemberian pertimbangan atau makna mengenai nilai dan arti dari sesuatu yang dipertimbangkan. Sesuatu yang dipertimbangkan tersebut dapat berupa orang, benda, kegiatan, keadaan, atau suatu kesatuan tertentu. Evaluasi adalah proses penentuan nilai atau harga dari data yang terkumpul. Pemberian pertimbangan mengenai nilai dan arti tidak dapat dilakukan secara sembarangan, oleh karenanya evaluasi harus dilakukan berdasar prinsip-prinsip tertentu. Setelah kita mengetahui perbedaan tentang tes, pengukuran, dan evaluasi kita dapat mengetahui hubungan di antara ketiganya.

Dengan demikian tes dan pengukuran adalah sesuatu yang tidak dapat dipisahkan. Tetapi tidak demikian halnya antara pengukuran dan evaluasi. Pengukuran menyediakan sarana yang dapat digunakan untuk mengumpulkan informasi yang diperlukan, tes adalah alat atau instrunem yang digunakan untuk mengumpulkan informasi.

Evaluasi adalah proses memberikan nilai atau harga dari data yang terkumpul. Melalui pengukuran data kuantitatif diproses dan dinilai hingga menjadi nilai yang bersifat kualitatif. Evaluasi harus merupakan kegiatan yang harus dilakukan terus menerus dari setiap program, karena tanpa evaluasi sulit untuk mengetahui jika, kapan, dimana, dan bagaimana perubahanperubahan akan dibuat.

Evaluasi tidak hanya terbatas dalam menggambarkan pengertian untuk menggambarkan status seseorang dibandingkan dengan anggota kelompok lainnya. Tetapi yang lebih penting, evaluasi dilaksanakan dalam rangka menggambarkan kemajuan yang dicapai oleh seseorang. Karena itu evaluasi harus dipahami sebagai bagian yang integral dari penyelenggaraan sebuah program, yang selalu berawal dari pemahaman terhadap siswa.

Tujuan Pengukuran dan Evaluasi Pengukuran dan evaluasi dalam bidang pendidikan pada umumnya dan keolahragaan khususnya mempunyai peranan yang sangat penting. Pengukuran dan evaluasi tersebut bertujuan untuk:

1. Pengelompokkan,

2. Penilaian

3. Motivasi

4. Penelitian.

Penentuan ini dapat digunakan untuk menentukan tingkat, membebaskan peserta dari suatu kesatuan pelajaran, menaikkan peserta dari suatu tingkat ke tingkat yang lebih tinggi, memberikan umpan balik untuk memperbaiki unjuk kerja, menempatkan individu-individu ke dalam kelompokkelompok tertentu atau menentukan suatu bentuk latihan yang khusus. Pada pokoknya, penentuan status mencakup semua tujuantujuan lain pengukuran dan evaluasi.

\section{Pengelompokkan}

Salah satu tujuan pengukuran dan evaluasi adalah untuk pengelompokan. Pengelompokkan ini dapat berdasarkan tingkat ketrampilan, umur, jenis kelamin, kondisi kesehatan, minat. Sebagai upaya untuk memperbaiki proses pembelajaran, guru dapat menempatkan siswanya ke dalam kelompok-kelompok tertentu, sesuai dengan tingkat kemampuannya.

Siswa dengan kemampuan yang tinggi tidak harus dipaksa bertahan dengan teman 
sekelompoknya yang berkemampuan kurang, demikian juga sebaliknya. Dengan dilakukannya pengukuran dan evaluasi siswa dapat dikelompokkan pada kelompok yang tepat.

Jika siswa ditempatkan dalam kelompok yang setara tingkat ketrampilannya, guru dapat menyusun program pelajaran secara individual. Keuntungan lain yang diperoleh dari pengelompokkan ini adalah siswa dapat berani, lebih lancar, lebih aktif ketika berlatih, karena mereka bersaing dengan siswa lain yang berkemampuan setara. Dengan kata lain, tujuan penempatan siswa ke dalam kelompok yang setara adalah untuk memperbaiki proses pembelajaran.

\section{Penilaian}

Tujuan utama dari penilaian ini adalah memberikan informasi tentang kemajuan yang dicapai dari proses pembelajaran yang dikerjakan dan posisi siswa di dalam kelompoknya. Dengan mempertimbangkan seluruh faktor, penilaian harus dilakukan secara objektif sehingga dapat mencerminkan kemajuan yang diperoleh, dan perbaikan-perbaikan yang diperlukan.

\section{Motivasi}

Motivasi merupakan kekuatan yang memandu seseorang untuk mencapai hasil yang tertinggi. Apabila dilaksanakan secara tepat, evaluasi dapat merupakan proses memotivasi yang positif. Demikian pula sebaliknya, bila dilakukan secara sembarangan evaluasi dapat mengurangi motivasi.

Motivasi yang terbesar adalah keberhasilan. Agar supaya siswa tetap memiliki motivasi, mereka harus mengetahui bahwa dirinya berkembang kemampuannya. Tes-tes ketrampilan olahraga memungkinkan siswa untuk berkompetisi dengan dirinya sendiri sebagai cara untuk mengukur kemajuannya.

\section{Penelitian}

Penelitian adalah penyelidikan yang dilakukan secara sistematis untuk meningkatkan ilmu pengetahuan. Mutu data yang dikumpulkan bergantung pada antara lain: ketelitian dan ketepatan alat ukur, teknik pengukuran, dan kelayakan tes. Dengan menggunakan tes unjuk kerja fisik dalam penelitian, dapat membantu guru/pelatih dalam menyusun program latihan yang tepat, membantu memecahkan masalah-masalah dalam proses pembelajaran, dan memperbaiki program latihan yang telah dijalankan. Dengan demikian penelitian dapat dianggap sebagai sarana. Dengan penelitian tumbuh pengetahuan yang dapat dikembangkan. Pengetahuan bergantung pada informasi yang tepat dan seksama atau data yang dikumpulkan melalui prosedur pengukuran yang direncanakan dengan hati-hati. Informasi dari data yang dikumpulkan untuk tujuan-tujuan penelitian harus dievaluasi akan keberartiannya. Jadi suatu tujuan yang penting dari pengukuran dan evaluasi adalah menyediakan sarana-sarana yang diperlukan untuk mengadakan

\section{PENGERTIAN UJIAN NASIONAL}

Menurut Kamus Bahasa Indonesia Online makna "ujian" adalah: uji.an [n] (1) hasil menguji; hasil memeriksa; (2) sesuatu yg dipakai untuk menguji mutu sesuatu (kepandaian, kemampuan, hasil belajar, dsb): kenaikan kelas diselenggarakan di sekolah masing-masing; (3) cobaan: musibah ini adalah $\sim$ dari Tuhan. 
Sedangkan Ujian Nasional biasa disingkat UN / UNAS adalah sistem evaluasi standar pendidikan dasar dan menengah secara nasional dan persamaan mutu tingkat pendidikan antar daerah yang dilakukan oleh Pusat Penilaian Pendidikan.

Depdiknas (sekarang Kemdikbud) di Indonesia berdasarkan Undang-Undang Republik Indonesia nomor 20 tahun 2003 menyatakan bahwa dalam rangka pengendalian mutu pendidikan secara nasional dilakukan evaluasi sebagai bentuk akuntabilitas penyelenggara pendidikan kepada pihak-pihak yang berkepentingan. Lebih lanjut dinyatakan bahwa evaluasi dilakukan oleh lembaga yang mandiri secara berkala, menyeluruh, transparan, dan sistematik untuk menilai pencapaian standar nasional pendidikan dan proses pemantauan evaluasi tersebut harus dilakukan secara berkesinambungan.

Lebih lanjut dinyatakan bahwa evaluasi dilakukan oleh lembaga yang mandiri secara berkala, menyeluruh, transparan, dan sistematik untuk menilai pencapaian standar nasional pendidikan dan proses pemantauan evaluasi tersebut harus dilakukan secara berkesinambungan. Proses pemantauan evaluasi tersebut dilakukan secara terus menerus dan berkesinambungan pada akhirnya akan dapat membenahi mutu pendidikan. Pembenahan mutu pendidikan dimulai dengan penentuan standar. Penentuan standar yang terus meningkat diharapkan akan mendorong peningkatan mutu pendidikan, yang dimaksud dengan penentuan standar pendidikan adalah penentuan nilai batas (cut off score). Seseorang dikatakan sudah lulus/kompeten bila telah melewati nilai batas tersebut berupa nilai batas antara peserta didik yang sudah menguasai kompetensi tertentu dengan peserta didik yang belum menguasai kompetensi tertentu. Bila itu terjadi pada ujian nasional atau sekolah maka nilai batas berfungsi untuk memisahkan antara peserta didik yang lulus dan tidak lulus disebut batas kelulusan, kegiatan penentuan batas kelulusan disebut standard setting.

Manfaat pengaturan standar ujian akhir:

1. Adanya batas kelulusan setiap mata pelajaran sesuai dengan tuntutan kompetensi minimum.

2. Adanya standar yang sama untuk setiap mata pelajaran sebagai standard minimum pencapaian kompetensi.

Penyusunan standard setting di atas dimulai dengan penentuan pendekatan yang digunakan dalam penentuan standar. Ada tiga macam pendekatan yang dapat dipakai sebagai acuan yaitu:

1. Penentuan standar berdasarkan kesan umum terhadap tes.

2. Penentuan standar berdasarkan isi setiap soal tes.

3. Penentuan standar berdasarkan skor tes.

Pada tiap-tiap akhir tahun kegiatan belajar diambil kesimpulan dan pembukuan standar setting berdasarkan tiga pendekatan tersebut untuk menentukan batas kelulusan. Ujian Nasional memang telah menjadi perdebatan setiap tahun di negeri ini yang tak kunjung reda. Di antara sebabnya adalah karena kegiatan yang telah berlangsung bertahun-tahun ini mengandung "Disparitas" (Perbedaan Yang Mencolok) dan "Proses Yang Tidak Berkesinambungan" dari proses pendidikan. 
Hal ini dapat kita lihat dari UndangUndang Republik Indonesia nomor 20 tahun 2003 yang menyebutkan bahwa: "Pendidikan adalah usaha sadar dan terencana untuk mewujudkan suasana belajar dan proses pembelajaran agar peserta didik secara aktif mengembangkan potensi dirinya untuk memiliki kekuatan spiritual keagamaan, pengendalian diri, kepribadian, kecerdasan, akhlak mulia, serta keterampilan yang diperlukan dirinya, masyarakat, bangsa dan negara."

Disini jelas bahwa perlu monitoring berkesinambungan dari "usaha sadar dan terencana" menuju "suasana belajar dan proses pembelajaran agar peserta didik secara aktif mengembangkan potensi dirinya".

Jelas perlu metoda dan alat ukur yang tepat guna agar peserta didik "memiliki kekuatan spiritual keagamaan, pengendalian diri, kepribadian, kecerdasan, akhlak mulia, serta keterampilan yang diperlukan dirinya, masyarakat, bangsa dan negara."

Secara filosofis UN/UNAS baik konsepnya, namun perlu ditekankan bahwa prosesnya tidak hanya ditekankan pada akhir tahun ajaran. la harus merupakan bagian "Sistem Pendidikan Berkelanjutan" yang dimonitor setiap waktu terhadap semua pemangku kepentingan utama pendidikan yaitu Kepala Sekolah, Guru, Peserta Didik, Tenaga Non-Kependidikan, Dinas Pendidikan, Kemdikbud bahkan Orang Tua/Wali.

\section{BARCODE}

Ujian tahun ini merupakan sebuah ujian yang dilakukan sistem barcode atau sebuah aplikasi kode yang hanya bisa dibaca oleh sistem seperti scaning yang berarti barcode adalah aplikasi pengkodean yang hanya bisa dibaca oleh system scaning, MENDIKBUD melakukan hal ini karena untuk mengurangi kecurangan dalam hal ujian nasional.

\section{PEMBAHASAN ANALISIS, KRITIS DAN EVALUASI \\ ANALISIS UJIAN NASIONAL 2013}

Selama ini penentuan batas kelulusan ujian nasional ditentukan berdasarkan kesepakatan antara pengambil keputusan saja. Batas kelulusan itu ditentukan sama untuk setiap mata pelajaran. Padahal karakteristik mata pelajaran dan kemampuan peserta didik tidaklah sama.

Hal itu tidak menjadi pertimbangan para pengambil keputusan pendidikan.

Belum tentu dalam satu jenjang pendidikan tertentu, tiap mata pelajaran memiliki standar yang sama sebagai standar minimum pencapaian kompetensi.

Ada mata pelajaran yang menuntut pencapaian kompetensi minimum yang tinggi, sementara mata pelajaran lain menentukan tidak setinggi itu. Keadaan ini menjadi tidak adil bagi peserta didik, karena dituntut melebihi kapasitas kemampuan maksimalnya.

Selanjutnya penulis mengumpulkan beberapa evaluasi selama Ujian Nasional tahun ini.

\section{Penentuan Kelulusan Ujian Nasional}

Penentuan kelulusan Ujian Nasional tahun 2013 dan tahun sebelumnya mengandung kontroversi. 
Badan Standarisasi Nasional Pendidikan (BSNP) bersama Kementerian Pendidikan Nasional dan Komisi X DPR memutuskan, tahun 2013 tetap ada Ujian Nasional (UN).

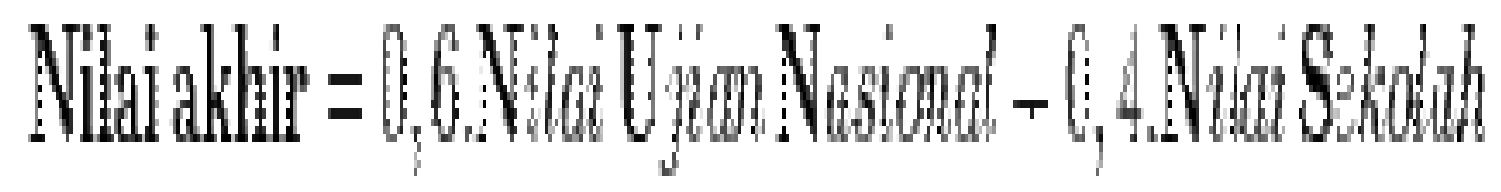

Standar nilai UN pada tahun ini direncanakan masih sama dengan tahun lalu, yakni 5,50 untuk SMP/SMA dan nilai Minimalnya sebesar 4,00, turun dari nilai tahun 2010 yang nilainya 4,25.

Dan untuk formula kriteria kelulusan tahun ini, pemerintah menggunakan formula baru. Kelulusan siswa dari sekolah dengan melihat nilai gabungan rencananya dipatok minimal 5,50. Nilai gabungan merupakan perpaduan nilai UN dan nilai sekolah untuk setiap mata pelajaran UN.

Nilai sekolah dihitung dari nilai ratarata ujian sekolah dan nilai rapor semester 1-5 untuk tiap mata pelajaran UN.

Dengan formula baru ini, rencananya akan dipatok nilai tiap mata pelajaran minimal 4,00. Integrasi nilai UN dan nilai sekolah ini diharapkan jadi pendorong untuk menganggap penting semua proses belajar sejak kelas 1 hingga kelas 3 .

Sedangkan kriteria kelulusan ujian sekolah diserahkan kepada sekolah. Nilai sekolah merupakan nilai rata-rata dari ujian sekolah dan nilai rapor semester 1-5 setiap mata pelajaran yang tidak diujikan dalam UN.

Hanya yang dibedakan dari tahun 2013 ini adalah dengan sebuah sistem baru yakni menggunakan barcode.

\section{KRITIS DAN EVALUASI UJIAN NASIONAL 2013}

\section{Kinerja Pengawas Belum Optimal}

Hal ini terjadi di kota Solo sebagaimana diberitakan Solo Pos bahwa masih banyak pengawas yang tidak menjalankan tugasnya dengan benar.

\section{Kualitas Lembar Jawaban}

Hal ini sebagaimana dinyatakan oleh Kepala Dinas Pendidikan Kota Yogyakarta Edy Heri Suasana menyatakan: "Tahun ini, banyak keluhan tentang kualitas lembar jawaban komputer sehingga hal ini akan menjadi fokus pada evaluasi pelaksanaan ujian nasional yang akan disampaikan ke provinsi,"

\section{Barcode yang Belum Maksimal}

Penggunaan barcode yang diujicobakan tahun ini membuat semakin tegang para pelajar karena membuat ketegangan yang meningkat pada psikologis anak sehingga tidak konsentrasi

dalam menjalani ujian nasional, selain itu bisa juga terjadi kesalahan dalam pembarcodean sehingga hasil ujian bisa menjadi nol atau nihil.

\section{Jual Beli Kunci Soal}

Sekalipun menggunakan barcode namun masih terjadi penjualan kunci jawaban. Dinas Pendidikan di berbagai 
daerah mensinyalir ada sindikat yang menjual belikan kunci soal.

Hal ini seperti yang dikatakan oleh Ketua Aliansi Orang Tua Peduli Pendidikan Handaru Widjatmoko: "Akan terjadi kecurangan bocor soal dan berbagai macam kekurangan lainnya. Kami kecewa sudah tahun lalu terjadi. Pemerintah janji tidak akan bocor. Soal tidak akan ada kecurangan. Namun setiap tahun terjadi seperti ini".

Sungguh kekacauan ujian nasional ini menandakan ketidaksiapan pemerintah menerapkan standar pendidikan nasional. Pemerintah pusat dan daerah belum menyentuh tujuh macam standar pendidikan nasional. Selain itu juga adanya perbedaan mutu pendidikan antara daerah dan pusat yang sangat besar terutama di daerah 3T (tertinggal, terpencil, dan terluar).

\section{PENUTUP}

\section{KESIMPULAN}

Di akhir penutup jurnal ini kita dapat memberikan kesimpulan bahwa secara filosofis UN/UNAS baik konsepnya, namun perlu ditekankan bahwa prosesnya tidak hanya ditekankan pada akhir tahun ajaran. la harus merupakan bagian "Sistem Pendidikan Berkelanjutan" yang dimonitor setiap waktu terhadap semua pemangku kepentingan utama pendidikan yaitu Kepala Sekolah, Guru, Peserta Didik, Tenaga NonKependidikan, Dinas Pendidikan, Kemdikbud bahkan Orang Tua/Wali.

Dan jika evaluasi itu ditujukan untuk melihat mutu pendidikan sekolah, maka seharusnya pemerintah menyerahkan semuanya kepada sekolah. Artinya biarkanlah pihak sekolah sendiri yang mengadakan ujian kepada siswanya. Sebab mereka itulah yang lebih mengetahui kemampuan anak muridnya. Peran pemerintah cukup mengawasinya saja. la menyakini masing-masing guru memiliki integritas pembuatan soal. Hal ini juga lebih mengefisienkan alokasi dana pelaksanaan UN.

Selanjutnya perbaikan yang dilakukan oleh pemerintah setelah evaluasi ini selesai diantaranya, perbaikan kurikurum, kualitas guru,dan sarana dan prasaranana. Dan tindak lanjut evaluasi UN ini sangat penting untuk memperbaiki kualitas pendidikan, misalnya apakah karena faktor gurunya, atau ruang kelasnya yang kurang memadai untuk kegiatan pembelajaran

\section{DAFTAR PUSTAKA}

At-Tarbiyyatu wa Turuqu Tadris, Sholeh Abdul Aziz dan Abdul Aziz Abdul Majid, Mesir: Darul Ma'arif,1979.

Education Psychology, Education Psychology, Education Psychology, California: Wads Worth Publishing Company, inc., 1959.

Frederick J. Mc. Donald, Education Psychology, (California: Wads Worth Publishing Company, inc., 1959), p. 4

Http://google.com.

http://jogja.antaranews.com/berita/300132 /kualitas-lembar-jawaban-un-jadifokus-evaluasi diakses tanggal 15 Mei 2012 jam 04.30 WIB.

http://pojokpendidikan.com/2012/04/14/uji an-nasional-antara-evaluasi-ataumonitoring-kinerja-proses- 
pembelajaran/, diakses tanggal 15

Mei 2012 jam 04.30 WIB.

http://www.kbr68h.com/perbincangan/guru -kita/22905-ujian-nasional-proyekpemerintah-atau-evaluasipendidikan, diakses tanggal $15 \mathrm{Mei}$ 2012 jam 04.30 WIB.

Sholeh Abdul Aziz dan Abdul Aziz Abdul Majid, At-Tarbiyyatu wa Turuqu Tadris, (Mesir: Darul Ma'arif,1979), hlm. 159.

Wikipedia Indonesia/ Evaluasi Ujian Nasional, diakses tanggal $15 \mathrm{Mei}$ 2012 jam 04.30 WIB. 